\title{
KEEFEKTIFAN PAIRED STORYTELLING DAN JIGSAW DALAM PENINGKATAN KOMPETENSI BERBICARA SISWA KELAS VIII SMP NEGERI 3 SLEMAN
}

\author{
Nurmiyati ${ }^{1)}$, Pujiati Suyata ${ }^{2)}$ \\ SMP Negeri 1 Jorong Tanah Laut Kalimantan Selatan ${ }^{1)}$,Universitas Negeri Yogyakarta ${ }^{2)}$ \\ nurmijrg@gmail.com ${ }^{1)}$, pujiati_suyata@uny.ac.id ${ }^{2)}$
}

\begin{abstract}
Abstrak
Penelitian ini bertujuan untuk mengetahui: (1) apakah ada perbedaan keefektifan antara teknik paired storytelling, jigsaw, dan konvensional dalam meningkatkan kompetensi berbicara siswa, (2) teknik pembelajaran berbicara yang paling efektif antara ketiga teknik penelitian itu dalam meningkatkan kompetensi berbicara siswa kelas VIII SMP Negeri 3 Sleman. Penelitian ini menggunakan jenis penelitian eksperimen semu dengan nonequivalent control-group design. Hasil penelitian menunjukkan bahwa: (1) Ada perbedaan keefektifan antara teknik paired storytelling, jigsaw, and konvensional itu dalam meningkatkan kompetensi berbicara siswa dengan nilai $\mathrm{F}$ sebesar 3,532 dan signifikan dengan $\mathrm{P}<0,05$, yaitu sebesar 0,033, dan (2) teknik paired storytelling adalah teknik keterampilan berbicara yang paling efektif diantara ketiga teknik itu dalam meningkatkan kompetensi berbicara siswa kelas VIII SMP Negeri 3 Sleman dengan mean tertinggi sebesar 74,3492.
\end{abstract}

Kata kunci: teknik paired storytelling, teknik jigsaw, teknik konvensional, kompetensi berbicara

\section{THE EFFECTIVENESS OF PAIRED STORY TELLING AND JIGSAW USE IN IMPROVEMENT STUDENTS' SPEAKING COMPETENCE IN SECOND GRADE SMPN 3 SLEMAN}

\begin{abstract}
The study aims at knowing (1) whether there is a difference of effectiveness among paired storytelling, jigsaw, and conventional techniques in improving the students' speaking competence, (2) the most effective speaking learning technique among those three techniques in improving the students' speaking competence at eighth grade in SMP N 3 Sleman. This study employed the quasi-experimental research. The study applied nonequivalent control-group design. The results of the study show that: (1) There is a difference of effectiveness among the paired storytelling, jigsaw, and conventional techniques in improving the students' speaking competence with $F$ value 3.532 and significance with $P$ $<0.05$, that is 0.033, and (2) the paired storytelling technique is the most effective technique among those three techniques in improving the students' speaking competence at eighth grade in SMP N 3 Sleman with the highest mean 74.3492 .
\end{abstract}

Keywords: paired storytelling, jigsaw, conventional technique, speaking competence. 


\section{PENDAHULUAN}

Bahasa Inggris adalah salah satu mata pelajaran yang penting di dunia pendidikan Indonesia. Pentingnya bahasa Inggris ini tercermin dari dijadikannya bahasa Inggris sebagai pelajaran wajib yang diajarkan di sekolah, mulai dari tingkat menengah pertama sampai Perguruan Tinggi. Badan Standar Nasional Pendidikan (BSNP, 2006, p.123) menetapkan bahwa pembelajaran bahasa Inggris ditargetkan agar siswa dapat mencapai tingkat berkomunikasi secara lisan dan tertulis. Berdasarkan hal tersebut, tampak jelas bahwa seseorang yang mempelajari bahasa Inggris diharapkan memiliki ilmu tentang bahasa Inggris dan memiliki kompetensi dalam bahasa itu, sehingga dengan hal itu ada bekal untuk menggunakan bahasa yang dipelajari di dalam kehidupannya.

Penggunaan bahasa Inggris dalam kehidupan merupakan salah satu bentuk tanggung jawab bagi seorang siswa dengan ilmunya, dan karena ilmunya ini pula akan menjadikannya seorang yang cakap, mandiri, dan kompeten dibidangnya, sehingga tujuan pembelajaran bahasa Inggris itu tidak hanya dapat menjawab pertanyaan dalam Ulangan Semester, Ujian Nasional, kemudian lulus dari satu jenjang sekolah, namun lebih kepada aplikasi penggunaan bahasa Inggris dalam komunikasi kehidupan yang nyata.

Berdasarkan tujuan pembelajaran bahasa Inggris di atas sehingga hal yang wajar ketika siswa belajar bahasa Inggris dituntut untuk dapat menginteraksikannya kepada orang lain. Oleh karena itu, salah satu keterampilan produktif dalam bahasa Inggris adalah keterampilan berbicara.

Adapun tujuan utama dari pembelajaran produktif, yang salah satunya berupa berbicara menurut Byrne (Hughes, 2002, p.67) adalah untuk mencapai kecakapan lisan. Kecakapan lisan ini dapat didefinisikan sebagai kemampuan untuk mengungkapkan sendiri sebuah ungkapan yang dapat dipahami, secara pantas, akurat, dan tanpa banyak keraguan. Dengan kata lain, kecakapan lisan ini adalah mampu berkomunikasi secara lisan dalam bahasa Inggris atau berbicara dalam bahasa Inggris. Untuk memperoleh tujuan ini, siswa dibawa dari tahap dimana mereka meniru sebuah model dari beberapa jenis, merespon sebuah kata atau tindakan, kepada saat dimana mereka dapat menggunakan bahasa secara bebas untuk mengungkapkan ide-ide mereka. Bagian dari kecakapan berbicara tergantung pada ke- mampuan seseorang untuk berbicara secara berbeda, tergantung pada latar belakang pendengar, dan bagaimana menangkap reaksi dan merespon mereka (Harmer, 2003, p.277). Seseorang yang berbicara harus mampu mengevaluasi efek komunikasinya terhadap para pendengarnya dan harus mengetahui prinsip-prinsip yang mendasari segala situasi pembicaraan, baik secara umum maupun perorangan.

Untuk mencapai suatu tujuan yang besar, berbicara dalam bahasa Inggris bukan merupakan sesuatu hal yang mudah untuk diraih. Oleh karena itu, diperlukan strategi serta teknik yang tepat untuk mencapai tujuan ini, dimana strategi dan teknik ini mampu melatih peserta didik dalam menggunakan bahasa itu, saling berinteraksi satu dengan yang lain menggunakan bahasa Inggris. Hal ini sebagaimana yang disebutkan oleh Nunan (Richards, 2002, p.209) bahwa dalam merencanakan kegiatan, guru arus mempertimbangkan semua keterampilan, sehingga siswa dapat berinteraksi dengan yang lain secara alami seperti dalam kehidupan nyata dan menurut Richards \& Renandya (2002, p.209) bahwa kegiatan interaktif yang efektif selain komunikatif juga harus dapat menggerakkan dan memaknai, sehingga dapat melibatkan siswa dalam menggunakan bahasa Inggris.

Adapun ketika melihat dari tuntutan zaman pada masa ini dimana manusia hidup pada masa teknologi informasi yang semakin tinggi dan canggih, sehingga tidak bisa dipungkiri lagi bahwa kemampuan berkomunikasi dalam bahasa Inggris menjadi sesuatu hal yamg urgen dan menjadi kebutuhan bagi manusia. Bahkan dalam pembelajaran Hall (2001, p.230) menekankan 'If we want our pupils or students to learn English, we must put them in situationasi where they need to communicate in English'. Menurut Hall, jika seorang guru mengajarkan bahasa Inggris, peserta harus dikondisikan ke dalam sebuah situasi dimana kondisi itu yang membuat siswa merasa perlu berkomunikasi dalam bahasa Inggris. Jadi, kondisi ini yang membutuhkan kekreativitasan bagi seorang guru untuk menciptakannya, baik kondisi ini tetap menjadikan ruang kelas sebagai tempat belajar dengan modifikasimodifikasi baru maupun tempat belajarnya di luar kelas sebagai suasana baru.

Melihat dari ketetapan pemerintah dan perkembangan dunia saat ini seperti terjadi kontradiksi dengan apa yang terjadi di lapangan baik dilihat dari sisi peserta didiknya maupun teknik yang diterapkan. Dari peserta didiknya, mereka belum menyadari sepenuhnya penting 
dan urgennya bahasa Inggris sebagai alat komunikasi yang harus mereka kuasai dan menggunakannya. Meskipun, peserta didik yang ditemui di lapangan di SMP Negeri 3 Sleman, mereka memiliki kemampuan mengungkapkan dalam bahasa Inggris dan merespon ungkapan itu meskipun masih pada tahap yang masih sangat sederhana, seperti pertanyaan dan respon tentang identitas diri dan deskripsi sesuatu mengenai warna, bentuk, dan sifatnya namun mereka belum menyadari sepenuhnya untuk mempraktikkan atau menggunakan bahasa yang mereka pelajari di dalam kelas di luar jam pelajaran bahasa Inggris maupun di luar kelas.

Adapun mekanisme dan teknik yang digunakan untuk aktivitas berbicara di dalam kelas untuk melatih siswa berbicara bahasa Inggris, siswa hanya diminta untuk menjawab pertanyaan secara lisan per individu. Aktivitas itu pun tidak meminta siswa secara bergiliran, namun pertanyaan itu diajukan kepada seluruh siswa yang ada dalam suatu kelas, sehingga yang menjawab semua pertanyaan siswa hanya beberapa orang siswa, dan mereka adalah orang yang sama pada hampir setiap kali guru mengajukan pertanyaan. Mereka adalah siswa yang termasuk mempunyai kemampuan yang tinggi dibandingkan siswa yang lain. Hal ini membuat proses pembelajaran bahasa Inggris hanya beredar pada sebagian siswa saja.

Belajar berkelompok kadang-kadang juga dibentuk untuk memfasilitasi siswa dapat belajar bersama dan berinteraksi satu sama lain, hanya saja kelompok ini tidak dibentuk berdasarkan kemampuan dan latar belakang siswa yang berbeda, namun hanya berdasarkan posisi tempat duduk atau secara acak tanpa memperhatikan kondisi siswa. Hanya saja, tidak semua siswa berada pada posisi duduk bersama dengan siswa yang mempunyai kemampuan dan latar belakang yang berbeda, Hal ini membuat kompetensi berbicara hanya beredar pada siswa yang sama, dan membuat keadaan yang sama atau tidak ada perubahan yang lebih baik pada siswa yang lain.

Keadaan dalam kelompok juga terkesan tidak alami, artinya sebuah kelompok tidak dibentuk agar siswa bekerjasama dalam menyelesaikan tugas, namun hanya dibentuk untuk dapat membaca dialog dalam buku pelajaran atau LKS ke depan kelas, dan terkadang dibentuk sesaat sebelum kelompok membacakan dialog ke depan. Hal ini membuat siswa tidak terdorong untuk mempersiapkan sesuatu atau percakapan yang lebih baik dan itu berjalan hanya sebagai sesuatu yang biasa.

Kurangnya strategi kelompok yang digunakan dalam pembelajaran keterampilan berbicara bahasa Inggris juga menjadi faktor minimnya penggunaan bahasa oleh siswa. Berdasarkan survei yang dilakukan kepada guru dengan memberikan pertanyaan-pertanyaan tentang teknik yang pernah diterapkan dalam pembelajaran bahasa Inggris, khususnya untuk keterampilan berbicara, maka diketahui bahwa teknik yang digunakan selama ini adalah teknik konvensional. Teknik konvensional dalam keterampilan berbicara ini dilakukan dengan guru memberikan contoh dialog atau percakapan dalam buku pelajaran bahasa Inggris atau LKS, kemudian siswa secara berpasangan mempraktikkan dengan membacakan dialog atau percakapan itu di depan kelas, dan juga pertanyaanpertanyaan yang diberikan kepada siswa yang dijawab secara individu.

Berdasarkan hal-hal tersebut, teknik pembelajaran yang memunculkan semangat siswa untuk belajar bahasa Inggris, melatih penggunaan bahasa Inggris, mempraktikkannya menjadi sebuah kebiasaan dan membangun kebutuhan berkomunikasi dalam bahasa Inggris merupakan hal yang penting dalam pembelajaran bahasa Inggris ini. Karena dalam berbicara ini seperti yang dinyatakan oleh Strickland et al (2007, p.53) bahwa "Students need opportunities to talk for a variety of purposes and in variety of contexts". Menurut Strickland kesempatan yang diberikan kepada siswa untuk berbicara bisa memiliki berbagai tujuan dan dalam beragam konteks, sehingga siswa merasa memiliki keleluasaan untuk mengungkapkan apa yang dia inginkan dan tidak merasa terbebani dengan ungkapan maupun kata yang tidak diketahui.

Pembelajaran kooperatif sebagai pembelajaran dengan dasar kelompok, tempat berkumpulnya siswa dengan latar belakang dan kemampuan yang berbeda satu sama lain, siswa dapat membahas dan mendiskusikan sebuah materi atau topik yang dilakukannya secara bersama-sama. Ketika ada siswa yang tidak mampu memahami sebuah materi pelajaran seorang diri, dengan berkelompok dia dapat bertanya dan mendengarkan penjelasan dari teman-temannya yang lain, bagi siswa yang mampu belajar sendiri, dengan berkelompok dia bisa belajar bersosialisasi atau bermasyarakat, meskipun dalam skala yang masih kecil. Hal ini karena dalam kelompok, siswa belajar mengungkapkan pendapat, mendengarkan pendapat orang lain, 
menghargai pendapat orang lain, menyanggah pendapat orang lain dengan cara yang baik, dan lain-lain pelajaran yang bisa diambil dalam pembelajaran berkelompok ini.

Hal ini tepat ketika Arends menyatakan bahwa sistem reward-nya pembelajaran kooperatif berorientasi pada individu dan kelompok, karena kesuksesan individu akan menentukan kesuksesan kelompok, dan sebaliknya. Selengkapnya Arends (2008, p.5) menyebutkan ciri-ciri pembelajaran kooperatif sebagai berikut. (1) Siswa bekerja dalam tim untuk mencapai tujuan belajar, (2) Tim-tim terdiri atas siswa-siswa yang berprestasi rendah, sedang dan tinggi, (3) Bilamana mungkin, tim-tim itu terdiri dari campuran ras, budaya dan gender, (4) Sistem reward-nya berorientasi pada kelompok dan individu.

Apabila dihubungkan pembelajaran berkelompok ini dengan tujuan belajar bahasa untuk berkomunikasi, dengan berkelompok ini masing-masing anggota kelompok dapat berinteraksi satu sama lain dalam menyampaikan pendapatnya, pemahamannnya, bertanya, menjawab pertanyaan, menceritakan suatu cerita, dan aktivitas-aktivitas verbal lainnya. Ketika siswa bergabung di dalam kelompok, mereka dapat dipastikan bahwa satu sama lain saling berinteraksi dan mendengarkan apa yang disampaikan oleh anggota kelompoknya, sehingga hal ini dapat membantu mereka dalam bersosialisasi dan aktif berkomunikasi. Oleh karena itu, penelitian ini mengangkat model cooperative learning dengan paired storytelling dan jigsaw sebagai tipe model pembelajaran yang digunakan, khususnya dalam meningkatkan kompetensi berbicara.

Adapun tujuan dari penelitian ini adalah mengetahui apakah ada perbedaan keefektifan antara teknik pembelajaran paired storytelling, jigsaw, dan konvensional. Selain itu pula, untuk mengetahui teknik pembelajaran yang paling efektif di antara teknik paired storytelling, jigsaw, dan konvensional dalam meningkatkan kompetensi berbicara bahasa Inggris jenis teks narrative siswa kelas VIII SMP Negeri 3 Sleman.

Teknik paired storytelling dan jigsaw diterapkan dalam penelitian ini karena kedua teknik ini tepat ketika menggunakan retelling stories sebagai aktivitas intinya. Keduanya mempunyai langkah yang mengakomodir terjadinya retelling stories ini. Berdasarkan hal ini, aktivitas inti dapat semakin lancar digunakan ketika langkah-langkah dalam kedua teknik ini mendukung aktivitas inti dan menjadikan tujuan pembelajaran dengan penerapan kedua teknik ini dapat tercapai. Hal ini sebagaimana yang disebutkan oleh masing-masing pakar dari kedua teknik ini yang menyebutkan langkah-langkah kedua teknik ini. Aktivitas-aktivitas dalam paired storytelling menurut Anita Lie (1994, pp.3-4) adalah sebagai berikut, (1) guru memasangkan dua siswa, (2) guru memperkenalkan topik melalui brain-storming, (3) teks atau cerita ini dibagi ke dalam dua bagian. LKS kelompok 1 untuk kelompok 1, dan LKS kelompok 2 untuk kelompok 2, (4) guru meminta siswa untuk menulis kata-kata kunci dan membatasi katakata kunci yang ditulis, (5) saling bertukar kata kunci, (6) menulis sebuah cerita, (7) berdasarkan daftar kata-kata kunci dan bagian cerita yang didapatkan, siswa yang mendapatkan bagian cerita yang pertama, maka mereka menuliskan cerita bagian kedua, sedangkan siswa yang mendapatkan bagian cerita yang kedua, menuliskan cerita bagian yang pertama, (8) menceritakan cerita kembali cerita yang ditulis, (9) tahap berikutnya adalah fasilitator/guru mendistribusikan bagian-bagian cerita siswa yang dihilangkan, kemudian tugas siswa membaca bagian cerita yang baru diperoleh, kemudian dibandingkan dengan cerita karangan mereka, (10) mendiskusikan seluruh cerita dengan pasangan-pasangan kelompok mereka, (11) fasilitator/guru mengadakan kuis untuk siswa yang merupakan tes formatif karena ini dilaksanakan setelah diselesaikannya 1 unit cerita.

Adapun teknik jigsaw II, Borich (2007, p.389), mengungkapkan mekanisme jigsaw II sebagai berikut, guru menugaskan siswa untuk membentuk tim dengan anggota empat sampai enam orang untuk bekerja melaksanakan tugas yang dibagi menjadi sub-sub tugas. Ketika semua anggota sudah mendapatkan tugasnya masing-masing, semua siswa keluar dari kelompok asal menuju kelompok ahli yang mempunyai tugas yang sama untuk mendiskusikan tugas, dalam hal ini retelling stories. Siswa bisa membandingkan catatan dan mengidentifikasi hal-hal yang penting dari anggota kelompok yang lain. Ketika semua diskusi dalam kelompok ahli berakhir, siswa kembali ke kelompok asal. Masing-masing anggota kemudian menyampaikan secara bergiliran apa yang sudah menjadi tanggung jawab mereka. Sesudah semua anggota tim memberikan presentasi anggota kelompok masing-masing, mengajarkan kepada teman satu kelompok apa yang didiskusikan dalam kelompok ahli, memberikan kuis 
atau pertanyaan individu untuk menilai seberapa banyak yang sudah dipelajari. Guru dapat menugaskan pada siswa untuk memberikan nilai secara keseluruhan atau individu berdasarkan performa terakhir. Nilai-nilai ini menjadi dasar untuk tim dan reward individu untuk nilai-nilai tertinggi.

Berdasarkan hal itu, penelitian ini menggunakan dua teknik pembelajaran, yaitu paired storytelling dan jigsaw, karena keduanya termasuk dalam kerja kelompok, satu sama lain mempunyai waktu terbatas untuk mengungkapkan pendapatnya, dan diharuskan untuk semuanya terlibat dalam membahas suatu topik, menyampaikan ungkapan atau menceritakan sesuatu pada orang lain, sehingga diharapkan tidak ada satupun siswa yang tidak menyampaikan ceritanya. Siswa yang mempunyai kompetensi lebih tinggi, dia akan bersemangat menyampaikan ceritanya dan membantu teman-temannya yang mengalami kesulitan dalam kosakata dan pengucapan, sedangkan siswa yang mempunyai kompetensi rendah, mereka tidak merasa enggan dan malu, bahkan merasa terbantu karena dia bisa menanyakan kosakata dan bagaimana pengucapan yang benar dari suatu kata, sehingga suasana saling membantu dan menghargai tercipta dalam kelompok-kelompok ini.

Dalam model pembelajaran kooperatif, paired storytelling sebagai tipe pembelajaran yang mengajak siswa untuk memunculkan memori dan imajinasi siswa dalam membentuk sebuah cerita yang belum mereka ketahui sepenuhnya dan bagian ceritanya yang lain sudah siswa ketahui melalui tugas yang diberikan guru kepada mereka. Menurut Aiex et al (Jianing 2007), teknik ini tidak hanya memberikan stimulus pada imajinasi dan pemahaman dunia mereka, tetapi juga mengembangkan kemampuan bahasa siswa dan memberikan apresiasi pada sastra (http://iteslj.org/indexPrev07.html). Bahkan Horner dan Ryf (2007, p.22) merekomendasikan untuk storytelling ini menjadi bagian integral dan esensi dalam lingkungan pembelajaran di lingkungan kelas. Ketika hal ini menjadi kebiasaan, suatu waktu siswa diminta untuk merespon secara lisan atau untuk mengungkapkan sesuatu dalam bahasa Inggris mereka siap dan tidak takut walaupun apa yang diungkapkan kemudian ada kesalahan.

Pada model pembelajaran kooperatif tipe jigsaw II, adanya kelompok asal dan kelompok ahli menfasilitasi siswa untuk saling berinteraksi satu sama lain dan melaksanakan tugas mereka masing-masing. Dalam hal ini tugas me- reka adalah saling menceritakan kembali cerita yang mereka pelajari. Menurut Browne (2009, p.9 \& 12), jigsaw merupakan salah satu situasi dimana siswa mendapatkan kesempatan untuk berbicara, dimana selain berbicara di dalam kelompok ahli, juga berbicara di dalam kelompok asal, kemudian di dalam kelompok asal ini, semua anggota kelompok asal bekerja bersama untuk menyelesaikan tugas. Hal ini juga yang dinyatakan oleh Qian \& Seepho (2012, p.298) bahwa selama jigsaw ini, siswa mendapatkan banyak kesempatan untuk berbicara dan menjadi lebih fasih dalam menggunakan bahasa. Hal tersebut terjadi karena masing-masing individu mempunyai kesempatan berkontribusi secara bermakna dalam kelompok (http://www.awej.org). Dengan demikian, Penggunaan teknik paired storytelling dan jigsaw dalam belajar berbicara dalam bahasa Inggris dapat menggali potensi yang dimiliki oleh siswa dan memotivasi siswa untuk mengungkapkan sesuatu dalam bahasa Inggris yang akhirnya dapat meningkatkan kompetensi berbicara dalam bahasa Inggris.

Manfaat teoritisnya berkaitan dengan penerapan model pembelajaran beserta pendekatannya, khususnya model pembelajaran kooperatif dengan teknik paired storytelling dan jigsaw bisa meningkatkan prestasi dan kompetensi siswanya dalam berbicara bahasa Inggris. Secara teoritis penelitian terhadap keefektifan paired storytelling dan jigsaw dapat memberikan manfaat dalam pengembangan keterampilan berbicara bahasa Inggris berikutnya.

Adapun teks yang digunakan dalam penelitian ini adalah teks naratif, dan aktivitas yang dilakukan siswa dalam rangka untuk meningkatkan kompetensi berbicara adalah retelling stories atau menceritakan kembali ceritacerita. Teks naratif adalah teks yang mengungkapkan cerita pada masa lampau yang mungkin bisa terjadi, atau benar-benar tidak terjadi atau kejadiannya di luar jangkauan manusia, dengan kata lain cerita fiksi yang terdiri dari legenda, mitos, dongeng, dan lain-lain. Cerita-cerita semacam ini dikenal banyak oleh siswa, sejak mereka bersekolah di tingkat dasar, bahkan menjadi pengantar tidur mereka. Selain itu, teks ini juga mempunyai struktur bahasa yang memudahkan siswa untuk mengingat atau menghafalnya, sehingga tepat digunakan dalam aktivitas retelling stories.

Berdasarkan hal tersebut, maka penelitian ini mengangkat judul "Kefektifan Penggunaan Paired Storytelling dan Jigsaw dalam Pening- 
katan Kompetensi Berbicara Bahasa Inggris Siswa kelas VIII SMP Negeri 3 Sleman”.

\section{METODE}

\section{Jenis Penelitian}

Jenis penelitian ini menggunakan eksperimen semu, karena di dalam penelitian ini akan menerapkan teknik-teknik pembelajaran di dalam kelas dalam rangka mencapai tujuan tertentu, dalam hal ini meningkatkan kompetensi berbicara siswa. Namun juga tetap ada kelas yang menjalankan teknik konvensional sebagai kelas kontrol dalam penelitian ini. Teknik-teknik yang akan dilihat keefektifannya adalah teknik paired storytelling dan jigsaw dalam meningkatkan kompetensi berbicara siswa.

Desain yang digunakan dalam penelitian ini adalah nonequivalent control group design (Gall \& Borg, 2003, p.402). Dalam desain ini terdapat tiga kelompok yang dipilih secara acak dan diasumsikan ketiga kelompok memiliki karakteristik yang sama (homogen). Dua kelompok diberi perlakuan (eksperimen), dan satu kelompok dijadikan sebagai kelompok kontrol. Pada ketiga kelompok diberikan pengamatan kompetensi berbicara tahap awal (soal dan mekanismenya sama), kemudian diberikan perlakuan khusus untuk kelompok eksperimen, dan akhirnya diberikan pengamatan kompetensi berbicara tahap akhir (soal dan mekanismenya sama). Hasil ketiga pengamatan kompetensi berbicara tahap akhir dibandingkan atau diuji perbedaannya. Pengamatan kompetensi berbicara tahap awal dan tahap akhir pada masing-masing kelompok juga dibandingkan atau diuji perbedaannya. Jika antara pengamatan kompetensi berbicara tahap awal dan tahap akhir pada kelompok eksperimen menunjukkan perbedaan, maka terdapat pengaruh dari perlakuan yang diberikan.

Langkah-langkah penelitian yang dilakukan adalah (1) melakukan perizinan ke sekolah-sekolah, (2) melakukan pra-survey ke sekolah yang memberikan izinnya untuk mengadakan penelitian,(3) pembuatan instrumen dan melakukan ujicoba instumen, (4) mengadakan pertemuan dengan guru bahasa Inggris dalam rangka briefing tentang metode dan teknik yang akan diterapkan, (5) melaksanakan pengamatan kompetensi berbicara tahap awal, (6) melaksanakan penelitian dengan menerapkan teknik paired storytelling dan jigsaw pada kelompok eksperimen, dan menerapkan teknik konvensional pada kelompok kontrol, (7) mengadakan pengamatan kompetensi berbicara tahap akhir, (8) analisis data, (9) menyusun laporan tesis penelitian eksperimen.

\section{Tempat dan Waktu Penelitian}

Kegiatan pengumpulan data penelitian ini dilakukan di Sekolah Menengah Pertama (SMP) Negeri 3 Sleman sebuah sekolah yang berada di Jl. Magelang km. 10, Ngancar Tridadi, Kabupaten Sleman Yogyakarta, yang dilaksanakan pada tahun pelajaran 2011/2012, dari bulan April sampai Juni 2012.

\section{Target/Sasaran Penelitian}

Populasi dalam penelitian ini seluruh siswa di kelas VIII di SMP Negeri 3 Sleman, yang terdiri dari 6 kelas, yaitu kelas VIII A, B, C, D, E, dan F. Adapun subjek dalam penelitian ini adalah semua siswa yang ada di kelas VIII B, E, dan F. Tiga kelas tersebut, terdiri dari dua kelas sebagai kelompok eksperimen, yaitu kelas VIII B dan E, dan 1 kelas yang lain, yaitu kelas VIII F sebagai kelompok kontrol.

\section{Variabel Penelitian}

Variabel dalam penelitian ini ada dua, yaitu variabel bebas dan variabel terikat. Variabel bebasnya disini adalah teknik pembelajaran paired storytelling (X1), jigsaw(X2), dan metode konvensional (X3), sedangkan variabel terikatnya adalah kompetensi berbicara $\operatorname{siswa}(\mathrm{Y})$.

\section{Prosedur Eksperimen}

\section{Praeksperimen}

Prosedur Praeksperimen terdiri dari prasurvei, survei, pemberitahuan Observer tentang teknik dan penilaian kompetensi berbicara, bahan, berupa buku paket dan LKS, penentuan kelompok eksperimen dan kelompok kontrol, dan melakukan Pengamatan Kompetensi Berbicara Bahasa Inggris Tahap Awal

\section{Eksperimen}

Suatu eksperimen dikatakan valid apabila hasil yang diperoleh oleh siswa itu disebabkan oleh variabel bebas (yang dimanipulasi) yang berupa perlakuan, yaitu teknik yang diterapkan pada kelompok penelitian. Apabila hasil itu dapat diberlakukan di luar sekolah selain dari sekolah tempat penelitian diadakan.

Pascaeksperimen

Setelah perlakuan selesai dilaksanakan, ketiga kelompok penelitian diadakan pengamatan kompetensi berbicara tahap akhir dengan 
materi seperti pada pengamatan kompetensi berbicara tahap awal. Pengamatan kompetensi berbicara tahap akhir bertujuan untuk mengetahui seberapa besar pengaruh perlakuan yang berbeda pada ketiga kelompok.

\section{Validitas dan Realibilitas Instrumen}

Instrumen yang digunakan dalam penelitian harus memenuhi persyaratan untuk menjadi instrumen yang baik.

Validitas

Validitas menfokuskan pada kesesuaian pada pengukuran antara pengamatan dan apa yang hendak diukur. Validitas yang digunakan adalah validitas isi. Validitas isi seharusnya menerima prioritas tertinggi selama proses perkembangan instrumen. Validitas isi dilakukan oleh tim ahli. Validitas instrumen dalam penelitian ini terdiri dari validitas teoritik dan empiris.

\section{Validitas Teoritik}

Validitas teoritik instrumen tugas performansi disusun dengan mengikuti teori sehingga menghasilkan item yang relevan dan membantu siswa untuk melakukan tugas performansinya di depan kelas, kemudian dikonsultasikan kepada professional experts, yaitu Bapak Dr. J. Bismoko, dan Bapak Suhaini M. Shaleh, M.A. Validitas ini bertujuan untuk mengetahui apakah instrumen yang sudah dibuat itu sudah sesuai dengan kisi-kisi atau belum sesuai.

\section{Validitas Empiris}

Validitas ini diperoleh dengan mengadakan ujicoba instrumen yang telah divalidasi. Setelah ujicoba, dilanjutkan dengan perhitungan hasil ujicoba instrumen setiap kelas. Ujicoba instrumen diperiksa oleh dua rater yaitu Drs. Yadi, dan Dyah Rini Widiarti, S.Pd. Mereka menilai kompetensi berbicara bahasa Inggris siswa dengan menggunakan picture-cued task pada kelompok ujicoba. Hasil pemeriksaan ini diperoleh data korelasi yang kuat antar rater 1 dan rater 2.

\section{Reliabilitas}

Instrumen yang baik harus bersifat reliabel, yaitu bahwa instrumen yang digunakan untuk mengukur berkali-kali menghasilkan data yang sama (konsisten). Reliabilitas instrumen penelitian ini menggunakan pengujian interrater, baik pada pengamatan kompetensi berbicara tahap awal maupun tahap akhir. Reliabilitas interrater ini memperhitungkan tingkat reliabi- litas dari dua deretan skor yang diperoleh dari dua orang korektor atau penguji, yaitu Bapak Drs. Agus Sudarisman dan Ibu Sumaryani, S.Pd yang masing-masing melakukan penskoran terhadap sejumlah peserta yang sama dan penskoran dapat dilakukan bersamaan.

Hasil penelitian interrater itu kemudian dianalisis dengan product moment untuk mengetahui derajat hubungan antara rater 1 dan rater 2, dalam hal ini adalah hasil penilaian guru (Djiwandono, 2008, pp.187-188). Jika hasil kedua penilai tersebut mempunyai hubungan yang kuat, maka dapat disimpulkan bahwa kedua penilai mempunyai pemahaman yang sama terhadap instrumen yang sama.

\section{Teknik dan Instrumen PengumpulanData}

Teknik Pengumpulan Data

\section{Penugasan Performansi}

Teknik pengumpulan data dalam penelitian ini dilakukan dengan penugasan berbicara yang digunakan untuk pencapaian standar kompetensi, penugasan untuk performansi berbicara bahasa Inggris ini melalui picture-cued task dilakukan sebanyak dua kali, yaitu awal sebelum diberikannya perlakuan atau disebut juga dengan pengamatan kompetensi berbicara tahap awal, dan akhir sesudah diberikannya perlakuan atau disebut juga dengan pengamatan kompetensi berbicara tahap akhir. Pengamatan awal dan akhir ini untuk mengetahui seberapa berhasilnya penggunaan teknik yang diterapkan, untuk meningkatkan kompetensi berbicara siswa. Pengamatan ini dilengkapi dengan lembar penilaian performansi kompetensi berbicara. Penilaian ini menggunakan rubrik holistik untuk keterampilan berbicara, dalam hal ini retelling stories yang digunakan ketika pembelajaran berlangsung dan kriteria penilaian picture-cued task untuk pengamatan berbicara tahap awal dan tahap akhir.

\section{Observasi}

Observasi dilakukan di dalam kelas penelitian. Objek yang diobservasi adalah siswa dalam proses pembelajaran. Kegiatan observasi dilengkapi dengan panduan lembar observasi. Lembar observasi digunakan ketika melakukan pengamatan secara langsung pada saat berlangsung performansi siswa, baik dengan menggunakan teknik paired storytelling, maupun jigsaw. Observasi ini berlangsung selama eksperimen. 
Instrumen Pengumpulan Data

Instrumen yang digunakan untuk mendapatkan data yang sesuai dengan teknik pengumpulan data tersebut adalah instrumen lembar penilaian berbicara, dan pedoman observasi.

\section{Teknik Analisis Data}

Pengujian Prasyarat Analisis

Penelitian ini menggunakan statistik parametrik yang digunakan untuk menguji parameter populasi melalui statistik, atau menguji ukuran populasi melalui data sampel. Teknik statistik yang digunakan dalam penelitian ini adalah teknik Analisis Varians (Anava). Hasil perhitungan uji Anava dinyatakan dengan nilai F.

Dalam teknik analisis Anava, data harus memenuhi dua kriteria sebagai berikut.

\section{Uji Normalitas}

Uji ini dikenakan pada hasil pengamatan kompetensi berbicara tahap awal dan akhir untuk kelas eksperimen maupun kelas kontrol untuk mengetahui bahwa prestasi awal dan akhir siswa sesudah perlakuan yang diambil pada masing-masing kelas berdistribusi normal. Uji normalitas ini dilakukan dengan mengguna-kan uji Satu Sampel Kolmogorof-Smirnov (One Sampel Kolmogorof-Smirnov Test) pada SPSS 17 data akan berdistribusi normal jika signifikansi $\mathrm{P}>0,05(5 \%)$.

\section{Uji homogenitas}

Uji kesamaan varians (homogenitas) bertujuan untuk mengetahui apakah sampel berasal dari populasi yang homogen atau tidak dengan membandingkan variansinya. Uji homogenitas ini dilakukan terhadap hasil pengamatan kompetensi berbicara tahap awal dan akhir kelas eksperimen dan kelas kontrol. Pengujian homogenitas dilakukan dengan uji Levene statistic. Data akan homogen jika signifikansi $\mathrm{P}>0,05$. Homogenitas digunakan untuk mengetahui kesamaan varians antara ketiga kelompok. Variansvarians tersebut untuk diuji homogenitas perlu dilakukan uji statistik pada distribusi skor kelompok-kelompok yang bersangkutan.

\section{Analisis Data}

Anava digunakan untuk menguji tiga kelompok, dalam hal ini kelompok eksperimen, yang terdiri dari dua kelas, masing-masing menggunakan teknik paired storytelling dan jigsaw, dan kelompok kontrol menggunakan teknik konvensional. Dengan ketentuan jika P < 0,05 , artinya ada perbedaan keefektifan antara ketiga teknik yang digunakan, dan sebaliknya. Adapun tingkat keefektifan antara teknik paired storytelling, jigsaw, dan kelompok kontrol yang menggunakan teknik konvensional ini dapat dilihat dari uji Scheffe.

\section{HASIL DAN PEMBAHASAN}

Sebelum memberi perlakuan, ada pemberitahuan kepada guru tentang gambaran teknik yang akan diterapkan dan sistem penilaian, sehingga mereka tidak bingung dan mampu menjadi observer yang baik. Adapun kepada siswa yang diberitahukan sebelum perlakuan, yaitu terkait dengan teknik dari paired storytelling maupun jigsaw yang akan diterapkan, langkah-langkah untuk teknik-teknik itu, dan tujuan penerapannya, sehingga siswa benarbenar memahami apa yang seharusnya mereka lakukan dan untuk apa mereka melakukan itu.

Keadaan siswa sebelum perlakuan berdasarkan survei yang dilakukan bahwa siswa belum menjadikan bahasa Inggris sebagai bahasa komunikasi sehari-hari antara guru dan siswa, siswa dan siswa. Hari khusus untuk penggunaan bahasa Inggris di sekolah pun belum ada. Meskipun bahasa pengantar guru dalam pembelajaran ini adalah bahasa Inggris, namun mekanisme guru belum mengajak seluruh siswa untuk mempraktikkan dan mengungkapkan bahasa Inggris dalam pembelajaran ini. Adapun mekanisme yang biasanya dilaksanakan guru dengan mengajukan pertanyaan kepada seluruh kelas dan tidak ada penunjukan kepada salah satu siswa untuk menjawab pertanyaan atau merespon pernyataan itu, sehingga yang menjawab pertanyaan tersebut adalah siswa yang mempunyai kemampuan cukup tinggi saja, sedangkan mayoritas siswa masih berkomunikasi secara pasif dengan guru. Hal ini membuat kompetensi bahasa Inggris khususnya dalam berbicara tidak tereksplor dan terkoordinir dengan baik.

Sebagian siswa memahami apa yang disampaikan dan diungkapkan oleh guru mereka karena mereka sering mendengar guru mereka menyampaikan ungkapan itu. Mayoritas siswa tersebut juga mampu untuk mengungkapkan dalam bahasa Inggris dan merespon ungkapan itu meskipun masih pada tahap yang masih sangat sederhana, seperti pertanyaan dan respon tentang identitas diri dan deskripsi sesuatu mengenai warna, bentuk, dan sifatnya. 
Sebelum perlakuan dilakukan, kelompok penelitian diadakan uji normalitas untuk melihat apakah semua kelompok penelitian dalam keadaan berdistribusi normal atau tidak dan uji homogenitas untuk melihat apakah semua kelompok penelitian dalam keadaan homogen atau heterogen. Untuk melihat hasilnya, dapat dilihat hasil kedua uji tersebut sebagai berikut.

Tabel 1. Normalitas dan Homogenitas Kelompok Penelitian

\begin{tabular}{ccc}
\hline $\begin{array}{c}\text { Kelompok } \\
\text { Penelitian }\end{array}$ & $\begin{array}{c}\text { Pengamatan } \\
\text { Awal }\end{array}$ & $\begin{array}{c}\text { Pengamatan } \\
\text { Akhir }\end{array}$ \\
\hline $\begin{array}{c}\text { Paired } \\
\text { Storytelling }\end{array}$ & 0,377 & 0,131 \\
Jigsaw & 0,373 & 0,071 \\
Kel Kontrol & 0,398 & 0,213 \\
\hline
\end{tabular}

Berdasarkan tabel tersebut menunjukkan bahwa semua kelompok penelitian berdistribusi normal pada pengamatan awal maupun pada pengamatan akhir dengan signifikansi $\mathrm{P}>0,05$. Semua kelompok penelitian juga dalam keadaan homogen baik pada pengamatan awal maupun pada pengamatan akhir. Hal ini ditunjukkan dengan $\mathrm{P}>0,05$.

Sebelum diadakan perlakuan juga diuji tingkat sebaran siswa pada kelompok penelitian untuk melihat apakah ada perbedaan sebaran siswa antara kelompok eksperimen dan kelompok kontrol. Oleh karena itu, diadakan uji Anava untuk melihat perbedaan itu. Uji Anava dapat dilihat pada tabel berikut ini.

Tabel 2.

\begin{tabular}{cccccc}
\hline & $\begin{array}{c}\text { Sum of } \\
\text { squares }\end{array}$ & Df & $\begin{array}{c}\text { Mean } \\
\text { Square }\end{array}$ & Sig. \\
\hline $\begin{array}{c}\text { Between } \\
\text { groups }\end{array}$ & 364.430 & 2 & 182.215 & .793 & .456 \\
$\begin{array}{c}\text { Within } \\
\text { groups }\end{array}$ & 21607.386 & 94 & 229.866 & & \\
Total & 21971.815 & 96 & & & \\
\hline
\end{tabular}

Berdasarkan tabel tersebut nampak bahwa semua kelompok penelitian tidak ada perbedaan sebaran siswa. Hal ini bisa dilihat dari uji Anava di atas yang signifikansinya berada pada $\mathrm{P}>$ 0,05 , yaitu sebesar 0,456 . Hal ini berarti semua kelompok penelitian dalam keadaan sama dan penelitian bisa dilanjutkan kepada tahap berikutnya, yaitu pemberian perlakuan (treatment) pada semua kelompok penelitian dengan penerapan teknik pembelajaran.

Pada saat perlakuan, semua siswa pada ketiga kelompok penelitian dimotivasi untuk belajar berbicara dalam bahasa Inggris dengan menceritakan kembali cerita yang telah mereka baca, pahami, dan hafalkan sebelumnya. Semua siswa diyakinkan bahwa mereka semua mampu melakukan aktivitas retelling stories itu dan aktivitas-aktivitas yang lain yang menjadi bagian dalam penelitian ini. Setelah mereka melakukan aktivitas-aktivitas tersebut, diberikan penghargaan karena mereka telah berhasil melakukan aktivitas itu.

Peningkatan yang terlihat ketika perlakuan pada kelompok paired storytelling yang semula pada pengamatan awal berbicara bahasa Inggris yang mampu menceritakan gambar berdasarkan pertanyaan panduan yang diajukan melalui picture-cued task hanya dua belas orang dan itu pun hanya mampu menjawab pertanyaan yang menanyakan tentang jumlah; nama-nama hewan atau benda yang ada dalam gambar; lokasi dimana cerita mengambil tempat/pelaku utama; dan pendapat mereka tentang gambar. Yang sulit mereka ceritakan terkait dengan tema cerita dan apa yang dilakukan oleh pelaku dalam gambar. Sedangkan sisa siswa yang lain hanya mampu menceritakan gambar berdasarkan 1-3 pertanyaan panduan saja.

Pada pengamatan akhir yang mampu menceritakan gambar tersebut meningkat menjadi 27 orang. Mereka mampu menceritakan gambar pada picture-cued task berdasarkan 4-5 pertanyaan panduan tentang jumlah; nama-nama hewan atau benda yang ada dalam gambar; lokasi dimana cerita mengambil tempat/pelaku utama; pendapat mereka tentang gambar; dan tema cerita. Kelancaran dan pengucapan siswa juga terlihat lebih baik pada pengamatan akhir dibandingkan pada pengamatan awal.

Adapun peningkatan dalam jigsaw, karena setiap siswa pasti berada pada dua kelompok yang berbeda, yaitu kelompok asal dan ahli, kemudian kembali pada kelompok asal, mereka belajar bagaimana bekerja sama dalam tim, sehingga mereka terbiasa dengan suasana dalam kelompok; ada rasa tanggung jawab dan saling menghargai. Kepercayaan diri mereka juga meningkat dalam berbicara bahasa Inggris di depan teman mereka.

Peningkatan pada kelompok eksperimen 2 dengan menggunakan jigsaw sebagai teknik penelitiannya terlihat juga dari jumlah siswa yang mampu menceritakan gambar berdasarkan pertanyaan panduan. Siswa yang mampu menceritakan gambar berjumlah 11 orang dengan berdasarkan pada 3-4 pertanyaan tentang jumlah, nama-nama hewan atau benda yang ada dalam gambar, lokasi dimana cerita mengambil tempat, dan pelaku utama atau sifat/bentuk dari 
suatu benda. Sedangkan sisa dari jumlah siswa yang lain hanya mampu menceritakan gambar berdasarkan 1-3 pertanyaan panduan.

Adapun siswa yang mampu menceritakan gambar meningkat menjadi 24 orang pada pengamatan akhir dengan menceritakan gambar berdasarkan 4-5 pertanyaan panduan. Sisa siswa yang lain hanya mampu menceritakan gambar berdasarkan 1-3 pertanyaan panduan. Sama seperti halnya pada eksperimen 1 , dari sisi kelancaran dan pengucapan mereka juga meningkat, meskipun belum sempurna dan masih ada kesalahan dari sisi pengucapan dan grammar atau tata bahasa. Hal ini semua karena kebiasaan yang mulai dibangun mulai dari sejak awal penelitian dengan mengucapkan dan mengungkapkan sesuatu dalam bahasa Inggris dengan menghafal cerita dan menceritakan kembali cerita itu dengan kelompok mereka masingmasing.

Adapun kelompok kontrol, peningkatan juga terjadi pada kelompok kontrol ini. Jumlah siswa yang mampu menceritakan gambar berdasarkan 3-4 pertanyaan panduan itu berjumlah 8 orang pada pengamatan awal. Mereka menceritakan gambar tentang jumlah, nama-nama hewan atau benda yang ada dalam gambar, lokasi dimana mengambil tempat, dan pelaku utama atau sifat/bentuk dari suatu benda. Sedangkan sisa dari jumlah siswa yang lain hanya mampu menceritakan berdasarkan 1-3 pertanyaan panduan.

Adapun jumlah siswa yang mampu menceritakan gambar berdasarkan 3-4/5 pertanyaan panduan meningkat menjadi 19 orang pada pengamatan akhir dalam kelompok kontrol ini. Siswa yang lain hanya mampu menceritakan gambar berdasarkan 1-3 pertanyaan panduan. Kelancaran dan pengucapan siswa juga meningkat dalam kelompok ini. peningkatan ini tidak lepas dari aktivitas yang juga dilakukan pada kelompok ini yaitu retelling stories siswa. Namun, karena mereka tidak menerapkan teknik paired storytelling atau jigsaw sebagaimana kelompok eksperimen, sehingga frekuensi siswa untuk melakukan retelling stories lebih sedikit dibandingkan pada kelompok eksperimen. Hal ini juga berpengaruh terhadap hasil akhir dari pengamatan akhir yang dilakukan oleh kelompok ini.

Perbedaan ini dapat dilihat pada tabel berikut ini.
Tabel 3. Kel.Eksperimen 1

\begin{tabular}{lllll}
\hline & & Mean & Min & Max \\
\hline Peng.Awal & 2 & 60.4770 & 16.67 & 79.17 \\
Peng.Akhir & 2 & 74.3495 & 25.00 & 87.50 \\
& 4 & 67.4133 & 16.67 & 87.50 \\
\hline
\end{tabular}

Tabel 4. Kel. Eksperimen 2

\begin{tabular}{lllll}
\hline & & Mean & Min & Max \\
\hline Peng.Awal & 2 & 57.8784 & 25.00 & 79.17 \\
Peng.Akhir & 2 & 69.0767 & 33.33 & 87.50 \\
& 4 & 63.4776 & 25.00 & 87.50 \\
\hline
\end{tabular}

Tabel 5. Kel.Kontrol

\begin{tabular}{lllll}
\hline & & Mean & Min & Max \\
\hline Peng.Awal & 2 & 55.7462 & 25.00 & 79.17 \\
Peng.Akhir & 2 & 64.3950 & 25.00 & 83.34 \\
& 4 & 60.0706 & 25.00 & 83.34 \\
\hline
\end{tabular}

Berdasarkan tabel-tebel tersebut menguatkan bahwa ketiga kelompok penelitian tersebut terjadi peningkatan dari pengamatan awal ke pengamatan akhir. Hal ini nampak jelas dilihat dari perbedaan mean antara ketiga kelompok penelitian tersebut.

\section{Pengujian Hipotesis}

Pengujian asumsi normalitas dan homogenitas varians telah dilakukan dan terpenuhi. Ini artinya persyaratan parametrik uji hipotesis menggunakan Anava dapat dilakukan. Uji perbedaan kompetensi berbicara bahasa Inggris antara kelompok eksperimen dan kelompok kontrol dalam penelitian ini, baik kompetensi berbicara bahasa Inggris pada pengamatan awal maupun pada pengamatan akhir menggunakan Anava satu jalur.

\section{Hipotesis Pertama}

Hipotesis ini berbunyi 'Ada perbedaan keefektifan antara teknik paired storytelling, jigsaw, dan konvensional dalam meningkatkan kompetensi berbicara siswa'. Adapun mengenai diterimanya atau ditolaknya hipotesis ini dapat dilihat pada penjelasan berikut.

Dalam pembelajaran dengan teknik paired storytelling, sebagian besar siswa kompetensi berbicaranya lebih lancar, karena dengan penguasaan secara utuh terhadap cerita-cerita pada masa proses pembelajaran berlangsung memberikan pengaruh yang sangat berarti. Dari pengamatan awal, siswa yang mampu menceritakan gambar hampir secara keseluruhan hanya \pm 12 orang, pada pengamatan akhir meningkat hingga 27 orang yang mampu menceritakan gambar berdasarkan pertanyaan panduan yang telah disediakan. Peningkatan yang lain dari sisi 
pengucapan siswa juga lebih baik dari pengucapan pada pengamatan awal. Keberanian siswa dalam mengungkapkan cerita lebih terlihat, dan mereka tidak malu lagi untuk mengungkapkan cerita dalam bahasa Inggris, jika mereka tidak mengetahui arti katanya dalam bahasa Inggris, mereka mengungkapkannya dalam bahasa Indonesia.

Adapun contoh dari cerita yang diungkapkan oleh siswa pada pengamatan awal dan pengamatan akhir sebagai perbandingannya adalah sebagai berikut. Pada pengamatan awal tentang the crocodile and mousedeer:

Two animal. A crocodile and mouse-deer. The main is mousedeer. The picture about the crocodile and mousedeer.

Pada pengamatan akhir tentang Aladin:

There two people in the picture. Aladin and Princess Jasmine. They sit di atas permadani on the sky. They look happy because they can together. The picture about Aladin.

Adapun pembelajaran jigsaw juga terjadi peningkatan, meskipun peningkatan siswa yang mampu menceritakan gambar tidak sebanyak pada kelompok eksperimen 1. Ketika dalam pengamatan berbicara pada tahap awal yang mampu menceritakan sebagian besar gambar hanya dua belas orang, dalam pengamatan akhir meningkat dua kali lipat dari jumlah pada pengamatan awal. Pengucapan siswa pada pengamatan akhir kelompok ini juga lebih baik dibandingkan pada pengamatan lebih awal. Namun dalam kelompok ini improvisasi individu siswa terhadap cerita kurang bila dibandingkan dengan kelompok eksperimen 1 . Hal ini dapat dilihat dari cerita-cerita yang diungkapkan berikut ini dalam cerita The crocodile and mousedeer dan Aladin.

Cerita The crocodile and mousedeer:

Two animal in picture. The crocodile and mousedeer. They ..... river. .......The mousedeer safe to come back to land.

Cerita Aladin sebagai berikut:

Two person in picture. Aladin and princess. The man and woman fly. They look happy. They happy on......... The picture about Aladin.

Adapun kelompok kontrol, karena mereka juga mempunyai aktivitas inti yang sama, yaitu retelling stories, sehingga mereka juga cukup terbiasa dengan melakukan aktivitas retelling stories ini. Dengan kata lain, aktivitas berbicara di depan kelas sering juga mereka lakukan.
Namun, karena dalam proses pembelajarannya, aktivitas retelling stories ini mereka lakukan hanya sekali ketika mereka maju ke depan kelas, dan sebelumnya hanya proses membaca dan menghafal bagian masing-masing saja sehingga mereka cenderung hanya menguasai bagian cerita masing-masing. Hal ini mempengaruhi hasil pengamatan berbicara pada tahap akhir mereka.

Peningkatan siswa dalam berbicara bahasa Inggris di kelompok kontrol ini memang terlihat dari pengamatan awal kepada pengamatan tahap akhir dari sisi ungkapan yang dihasilkan, pengucapan mereka juga lebih baik, keberanian dalam berbicara siswa dalam kelompok ini juga bertambah. Namun, jumlah mereka yang meningkat tajam tidak sebanyak jumlah pada kelompok eksperimen. Siswa yang meningkat dalam berbicara bahasa Inggris pada pengamatan akhir di kelompok kontrol masih sedikit peningkatannya dari pengamatan awal. Siswa yang mampu menceritakan gambar berdasarkan pertanyaan panduan berjumlah 11 orang pada pengamatan awal dan meningkat menjadi 19 orang pada pengamatan akhir, sedangkan sisanya 14 orang masih belum mampu menceritakan gambar secara lebih lengkap berdasarkan pertanyaan panduan yang diberkan.

Berikut contoh cerita salah satu siswa yang meningkat dalam berbicara bahasa Inggris dalam kelompok kontrol. Cerita the crocodile and mousedeer pada pengamatan tahap awal:

Two animal. There crocodile and mousedeer. in river. Main mousedeer. About the crocodile and mousedeer.

Cerita Aladin pada pengamatan tahap akhir:

Two people in picture. Aladin and princess in the picture. They fly together because that look happy. The picture about Aladin.

Berdasarkan hal tersebut dapat dilihat bahwa ada perbedaan keefektifan antara ketiga kelompok penelitian tersebut dalam meningkatkan kompetensi berbicara siswa. Hal ini dilihat dari ungkapan yang mereka hasilkan itu lebih baik dari pengamatan awal, jumlah siswa yang mampu menceritakan gambar juga meningkat dari pengamatan awal, kelancaran dan pengucapan mereka juga meningkat dibandingkan sebelum adanya penelitian.

Secara keseluruhan hasil perhitungan hasil Anava tentang penggunaan teknik pembelajaran paired storytelling, jigsaw, dan konvensional dalam pembelajaran kompetensi berbicara bahasa Inggris siswa di SMP Negeri 3 Sleman 
Yogyakarta memperoleh hasil $\mathrm{F}$ sebesar 3,532 dan signifikan dengan $\mathrm{P}<0,05(5 \%)$, yaitu sebesar 0,033. Ini berarti Ho ditolak, dan H1 diterima. Hal ini dapat disimpulkan bahwa ada perbedaan keefektifan antara ketiga teknik paired storytelling, jigsaw dan konvensional tersebut dalam meningkatkan kompetensi berbicara bahasa Inggris siswa kelas VIII di SMP Negeri 3 Sleman Yogyakarta. Dengan demikian, hipotesis pertama ini diterima.

\section{Hipotesis Kedua}

Hipotesis kedua ini berbunyi 'teknik pembelajaran yang paling efektif dalam meningkatkan kompetensi berbicara adalah paired storytelling'. Adapun hasil dari uji hipotesis kedua ini dapat dijelaskan sebagai berikut.

Berdasarkan hasil pengamatan di lapangan dan pembahasan pada hipotesis pertama di atas dapat dilihat bahwa teknik yang paling efektif adalah paired storytelling dalam meningkatkan kompetensi berbicara siswa kelas VIII. Hal tersebut dapat dilihat pada dua faktor berikut. Pertama, proses pembelajaran, hasil pada aktivitas siswa yang berupa retelling stories dan kuis individu yang menunjukkan dikuasainya cerita secara utuh dan menyeluruh. Kedua, dari peningkatan jumlah siswa yang mampu menceritakan gambar berdasarkan pertanyaan panduan paling besar ada pada kelompok eksperimen 1 mencapai $80 \%$ dari pengamatan awal. Dari sisi kelancaran siswa dalam menceritakan gambar juga kelompok paired storytelling ini paling baik di antara kelompok jigsaw dan konvensional.

Teknik paired storytelling dari tahap awal menstimulus untuk penguasaan cerita secara penuh dan membantu meningkatkan kompetensi berbicara melalui brainstorming, pemahaman bagian cerita, melatih imajinasi dengan menulis cerita, retell a story, dan kuis individu. Teknik paired storytelling dalam langkah-langkahnya terdapat langkah-langkah untuk mengendapkan pemahaman dan kosakata pada langkah memahami cerita sebelum menulis kata-kata kunci, kemudian diungkapkan melalui karangan cerita dan aktivitas retelling a story. Aktivitas ini berulang beberapa kali selama penelitian berlangsung, sehingga memberikan pengaruh yang signifikan pada hasil akhir.

Siswa yang ada dalam teknik paired storytelling, peningkatannya mencapai $80 \%$. Peningkatannya meliputi siswa mampu menceritakan gambar sesuai dengan 4-5 daftar pertanyaan yang diajukan, padahal sebelumnya pada pengamatan awal sebagian besar siswa hanya mampu menceritakan gambar berdasarkan 1-3 daftar pertanyaan. Pada pengamatan akhir, siswa dalam menceritakan gambar tersebut lebih lancar dari pengamatan awal. Pengucapan mereka juga lebih baik. Improvisasi pada kelompok ini juga terjadi meskipun pada bentuk yang masih sederhana.

Teknik jigsaw merupakan teknik yang menuntut seorang siswa untuk menguasai bagiannya masing-masing, agar dia dapat menceritakan kepada teman dalam kelompok ahli sebagai bekal dia mengajarkan atau menyampaikan ceritanya kepada teman-teman sekelompoknya yang pertama yaitu kelompok asal, karena setiap siswa mempunyai tugas untuk mengajarkan bagiannya masing-masing kepada teman kelompok asalnya. Namun, kesadaran ini tumbuh dari rasa tanggung jawab seorang siswa sebagai anggota dari sebuah kelompok kepada anggota kelompoknya yang lain. Namun, ketika seorang siswa tidak atau kurang menyadari perannya dalam sebuah kelompok, maka kelompok tersebut tidak dapat mencapai tujuan individu-individu dalam kelompok maupun tujuan kelompoknya.

Berdasarkan hasil pengamatan di lapangan, siswa dalam kelompok eksperimen 2 dengan teknik jigsaw ini meningkat dari peng-amatan awal sebesar $75 \%$. Pengamatan awal yang mampu menceritakan gambar berdasarkan 4-5 pertanyaan hanya 12 orang, sedangkan pada pengamatan akhir meningkat menjadi 24 orang. Cara mereka dalam mengungkapkan cerita dalam gambar lebih lancar ketika pada pengamatan akhir dibandingkan pada pengamatan awal. Pengucapan mereka juga menjadi lebih baik.

Adapun teknik konvensional, anggota kelompok tidak bertanggung jawab sepenuhnya terhadap penguasaan anggota kelompok yang lain, karena mereka bertanggung jawab untuk diri mereka sendiri. Ketika mereka mampu retelling a story yang menjadi tugasnya, maka memenuhi syarat untuk mendapatkan nilai, namun jika tidak, mereka tidak akan mendapatkan nilai.

Adapun teknik konvensional langkahlangkahnya cukup pendek sampai pada aktivitas retelling stories, sehingga siswa belum cukup menguasai cerita secara keseluruhan, mereka sudah sampai pada tahap akhir proses teknik ini. Hal ini tidak seperti langkah-langkah pada teknik paired storytelling yang cukup panjang sampai pada tahap akhir, kuis individu. Akibatnya, mereka hanya menguasai bagian cerita mereka masing-masing. Hal ini pun berpengaruh pada 
hasil pengamatan akhir. Siswa juga menggunakan aktivitas retelling stories dalam kelompok kontrol ini, hanya intensitas retelling stories kepada yang lain jauh lebih sedikit, khususnya bila dibandingkan dengan jigsaw yang melakukan beberapa kali pengulangan dalam melakukan aktivitas ini.

Peningkatan siswa yang ada dalam teknik konvensional hanya mencapai 58\% dari total keseluruhan jumlah siswanya. Peningkatan siswa yang mampu menceritakan gambar sesuai dengan 4-5 pertanyaan hanya \pm 19 orang dari jumlah pada pengamatan awal yang hanya berjumlah 11 orang. Kelompok konvensional ini dalam pengungkapan cerita dalam gambar sering terputus-putus walaupun akhirnya siswasiswa dalam kelompok ini mampu menceritakan gambar sesuai dengan kemampuan mereka. Meskipun demikian, pengungkapan cerita dan pengucapan mereka juga lebih baik dari pengamatan awal. Sedangkan untuk siswa yang lain mereka hanya mampu menceritakan gambar berdasarkan 2-3 pertanyaan saja, meskipun dari cerita yang diungkapkan dan pengucapan juga lebih baik dari pengamatan awal.

Adapun berdasarkan statistik, uji Scheffe yang dilakukan untuk melihat dari ketiga teknik ini yang mana yang paling efektif dalam meningkatkan kompetensi berbicara bahasa Inggris siswa kelas VIII SMP Negeri 3 Sleman. Berdasarkan uji Scheffe juga menunjukkan teknik yang paling efektif adalah paired storytelling. Hal ini dapat dilihat pada tabel berikut ini.

Tabel 6.

\begin{tabular}{cccc}
\hline \multicolumn{2}{c}{ Kelompok Penelitian } & Mean Diff. & Sig. \\
\hline P.storytelling & Jigsaw & $5.27281^{*}$ & .381 \\
& Kontrol & 9.95529 & .033 \\
Jigsaw & P.storytelling & -5.27281 & .381 \\
& Kontrol & 4.68248 & .461 \\
Kontrol & P. storytelling & -9.95529 & .033 \\
& Jigsaw & -4.68248 & .461 \\
\hline
\end{tabular}

Adapun dilihat dari uji Scheffe yang dilakukan maka terlihat dari mean difference-nya ada tingkat perbedaan keefektifan antara ketiga teknik pembelajaran, paired storytelling, jigsaw, dan konvensional, yaitu teknik yang paling efektif dalam meningkatkan kompetensi berbicara bahasa Inggris kelas VIII SMP Negeri 3 Sleman adalah paired storytelling, kemudian diikuti teknik jigsaw dan konvensional. Namun, dilihat dari signifikansinya ada yang tidak signifikan perbedaannya antara teknik-teknik pembelajaran tersebut, khususnya antara teknik paired story- telling dan jigsaw, dan teknik jigsaw dan konvensional.

Berdasarkan hasil uji Scheffe tersebut dapat disimpulkan bahwa teknik pembelajaran yang paling efektif dalam meningkatkan kompetensi berbicara siswa SMP Negeri 3 Sleman adalah teknik paired storytelling, sehingga hipotesis kedua ini diterima.

\section{SIMPULAN}

Ada perbedaan keefektifan antara teknik paired storytelling, jigsaw, dan konvensional dalam meningkatkan kompetensi berbicara bahasa Inggris jenis teks narrative siswa kelas VIII SMP Negeri 3 Sleman. Teknik paired storytelling adalah teknik yang paling efektif untuk meningkatkan kompetensi berbicara bahasa Inggris jenis teks narrative siswa kelas VIII SMP Negeri 3 Sleman.

\section{DAFTAR PUSTAKA}

Arends. (2008). Learning to teach. (Terjemahan Helly Prajitmo Soetjipto \& Sri Mulyantini Soetjipto). $7^{\text {th }}$ ed. $2^{\text {nd }}$ book. Yogyakarta: Pustaka Pelajar. (Buku asli diterbitkan tahun 2007)

Borich, D. G. (2007). Effective teaching methoods: Research-based practice. New Jersey: Pearson Merrill Prentice Hall.

Browne, A. (2009). Developing language and literacy 3-8 (3 $3^{\text {rd }}$ ed). Los Angeles: SAGE.

Depdiknas. (2006). Standar isi untuk satuan Pendidikan Dasar dan Menengah, standar kompetensi dan kompetensi dasar SMP/MTs. Jakarta: BSNP.

Djiwandono, Soenardi. (2008). Tes bahasa pegangan bagi pengajar bahasa. Jakarta: Indeks.

Gall, M. D., Gall, J. P., \& Borg, W. R. (2003). Educational research an introduction. Boston: Pearson Education Inc.

Hall, R. D., \& Hewings, A. (2001). Innovation in English language teaching, a reader. London \& New York: The Open University, Routledge Taylor \& Francis Group, Macquarie University Sydney.

Harmer, J. (2003). The practice of English language teaching. $\left(4^{\text {rd }} e d\right)$. London: Pearson Longman. 
Horner , C., \& Ryf, V. (2007). Creative teaching: English in the early years and primary schools. London \& New York: Routledge Taylor \& Francis Group.

Hughes, R. (2002). Teaching and researching speaking. London: Pearson Education. Longman.

Jianing, X. (2007). Storytelling in the EFL speaking classroom. The Internet TESL Journal. Vol. XIII, No. 11. Diambil pada 28 Januari 2013, dari http:// Iteslj.org/indexPrev07.html.

Lie, Anita. (1994). Paired storytelling: An integrative approach for billingual and English as a second language students. Texas Reading Report. Diambil pada tanggal 17 November 2012 dari yeslife.files.wordpress.com/2008/10/pai red-storytelling.pdf.

Qian, L. \& Seepho, S. (2012). Foreign language speaking anxiety reduction through a jigsaw activity. Arab World English Journal. Vol. 3, No. 4, pp. 297-305. Diambil pada 28 Januari 2013 dari http://www.awej.org.

Richards, C. J., \& Renandya, A. W. (2002), Methodology in language teaching, an anthology of current practice. Cambridge: Cambridge University Press.

Strickland, D. S., Galda, L., \& Cullinan, B. E., (2007). Language arts: Learning and teaching. Canada: THOMSON WADSWORTH. 